\title{
Use of the Key Performance Index Evaluation Model for a Comparative Analysis of the Professional Teaching Quality of Economic Management
}

\author{
https://doi.org/10.3991/ijet.v16i24.27869 \\ Xiangpeng Chang \\ Shijiazhuang University of Applied Technology, Shijiazhuang, China \\ 2001000251@sjzpt.edu.cn
}

\begin{abstract}
The key performance index (KPI) evaluation provides a guarantee for discipline construction, talent training, and research development and planning in colleges. Based on KPI evaluation model, this paper compares the professional teaching quality of economic management of different types of colleges, different teaching models, and different disciplines, through KPI appraisal. The results show that: teaching quality can be evaluated by several important indices, namely, teaching attitude, teaching content, teaching method, and teaching effect; the most important indices are teaching attitude and teaching content, followed by teaching effect and teaching method. The index scores of professional education mode were much higher than those of general education mode. Teaching effect is the highest rated index among students of accounting, and teaching attitude is the highest rated index among students of business administration. The research results lay the theoretical basis for colleges to improve KPI appraisal system and appraisal supervision system.
\end{abstract}

Keywords-key performance index (KPI) evaluation, teaching mode, teaching quality, evaluation index, teaching effect

\section{$1 \quad$ Introduction}

The key to talent training lies in teaching quality. Colleges must concentrate their efforts on improving teaching effect and enhancing core competitiveness, striving to make breakthroughs in talent training and research innovation [1]. To ensure and improve teaching quality, colleges need to properly set their goals and missions, actively invest on and streamline school running, and accurately evaluate the school-running results measures $[2,3]$. More and more scholars are exploring the evaluation and supervision system of teaching quality in colleges. There is a surge of relevant literature in recent years (as shown in Figure 1).

Foreign colleges have developed a series of strategies to assure teaching quality. Australia created a quality supervision system composed of evaluation, optimization, reinterpretation, role assignment, and informatization strategies [4]. Some colleges in the United States incorporated the organizational management, supervision, evaluation, and criteria setting of teaching quality into the teaching quality guarantee system $[5,6]$. 
In Britain, the higher education quality guarantee system consists of an extramural guarantee system and an intramural guarantee system [7]. To assure teaching quality, Chinese colleges are gradually improving the rules and regulations on teaching management, including teaching inspection system, teaching evaluation system, and graduation qualification review system [8].

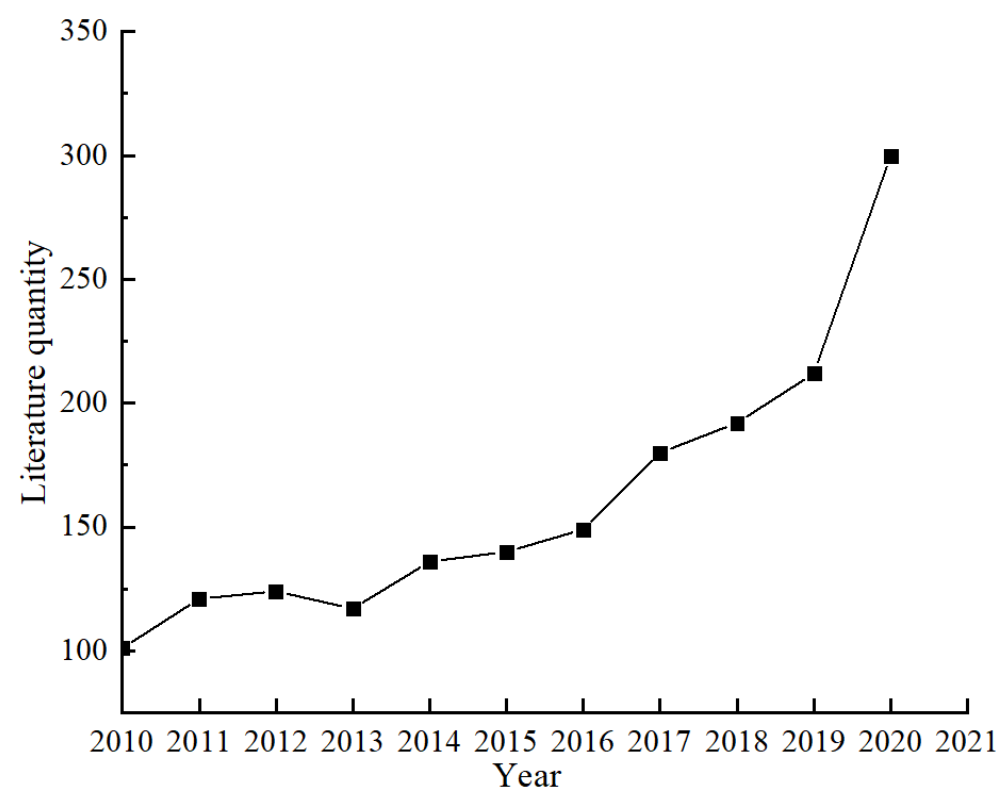

Fig. 1. Trend of literature quantity on teaching quality in colleges

Key performance index (KPI) evaluation model was initially applied to corporate management. There is a lag in its application to teaching quality evaluation $[9,10]$. The KPI appraisal system for teachers can promote their career development, encourage them to make teaching innovation, and improve the teaching management of colleges [11].

The department of economic management focuses on cultivating the professional capacity of students, such as professional ability, practical ability, and innovation ability [12]. This professional demand raises a high requirement on the teachers' professional capacity. To ensure teaching quality, the colleges must fully assess whether the teachers' professional capacity matches college development [13].

Some scholars learned that the KPI appraisal of teachers needs to consider the teaching management task of the college, and provide a scientific, systematic, and complete reference for faulty construction [14, 15]. KPI appraisal can enhance the professional capacity of teachers, create a positive team atmosphere, and promote the co-opetition management among teachers [16].

Based on KPI evaluation model, this paper compares the professional teaching quality of economic management of different types of colleges, different teaching models, and different disciplines, through KPI appraisal. 


\section{State quo of college teaching quality evaluation}

\subsection{Problems of teachers' KPI appraisal and their causes}

Teachers' KPI appraisal is critical to teaching and education [17]. The goals of KPI appraisal must be clear, easy to quantify, and in line with the actual situation of the teachers [18]. To fulfil these goals, the manager should clearly allocate the tasks of performance appraisal, while the teachers should enhance their cognitive ability, effectively control their defects, and pursue concrete improvements [19, 20].

Currently, many colleges have been designed KPI appraisal around the development goals of teachers. But there are many defects with the current designs [21]. Some of the most prominent problems are presented in Figure 2.

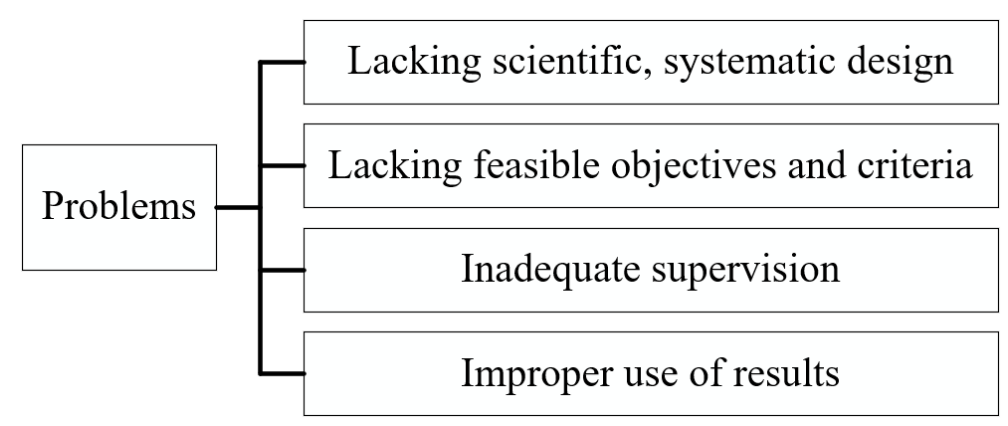

Fig. 2. Problems in teachers' KPI appraisal

Firstly, the KPI appraisal designs are rarely scientific and systematic. Questionnaire surveys have shown that, in some colleges, only $25 \%$ of the respondents are satisfied with the role of KPI appraisal in enhancing the professional capacity of teachers. The KPI appraisal goals cannot be realized, mainly due to the poor communication between the implementation department and the faculty [22].

Secondly, there is a lack of feasible objectives and criteria for KPI appraisal. In many colleges, teachers' KPI appraisal simply focuses on the amount of teaching tasks and research works. The uniqueness of the departments is not considered in the design of performance appraisal. To make matters worse, some rating criteria impede teachers from developing their own strengths [23].

Thirdly, KPI appraisal is not fully supervised. The teachers are not very satisfied with the composition of appraisal personnel and the construction of the appraisal system. The supervision of KPI appraisal becomes a major problem. The fairness of appraisal results is of great significance. To output fair results, the key is to build a closedloop KPI appraisal system, which put the subjects under supervision [24, 25].

Fourthly, the KPI appraisal results have not been utilized properly. Few teachers are satisfied with the appraisal, because their salary is not linked with the appraisal results.

Figure 3 displays the causes for the problems in teachers' KPI appraisal. The first cause is the insufficient attention to KPI appraisal. Colleges are often concerned with the appraisal results, paying little attention to the process of appraisal. Next, the KPI 
appraisal indices do not match the teaching task, and no closed-loop system is available for the appraisal. Moreover, there is a mismatch between appraisal design and the teaching task. In many colleges, KPI appraisal is merely a formality, because the appraisal results are fuzzy, and the personal goals of teachers differ from the development goals of the college. In addition, empirical experience is unavailable due to the absence of KPI appraisal supervision system. Finally, KPI appraisal is weakly correlated with other works, making it hard to obtain feedbacks on the results.

Causes \begin{tabular}{l|l|} 
Insufficient attention \\
Lacking supervision system \\
Weak correlations with other works \\
\hline
\end{tabular}

Fig. 3. Causes of the identified problems

\subsection{Constraints of teachers' KPI appraisal}

Teachers' KPI appraisal is affected by various factors. Figure 4 sums up the constraints on teaching quality appraisal in colleges. Firstly, the colleges emphasis too much on school-running scale, while overlooking the improvement of school-running capacity. Secondly, the shortage of funds and teachers drags down teaching quality, resulting in low scores of KPI indices. Thirdly, unscientific management hinders the supervision of teaching quality, and leads to unclear allocation of teaching management duties, making it impossible to achieve high-quality teaching in a sustainable manner [26]. Fourthly, many students face cultural shock, and lack enthusiasm about learning. Many of them lower their learning standards. The teaching effect is thereby weakened. Fifthly, the competition pressure is not enough to motivate the students. The lack of motivation is further worsened, as the training goals of many departments are inconsistent with the students' demand. Finally, there is a huge gap between the goals of talent training and the actual demand. 


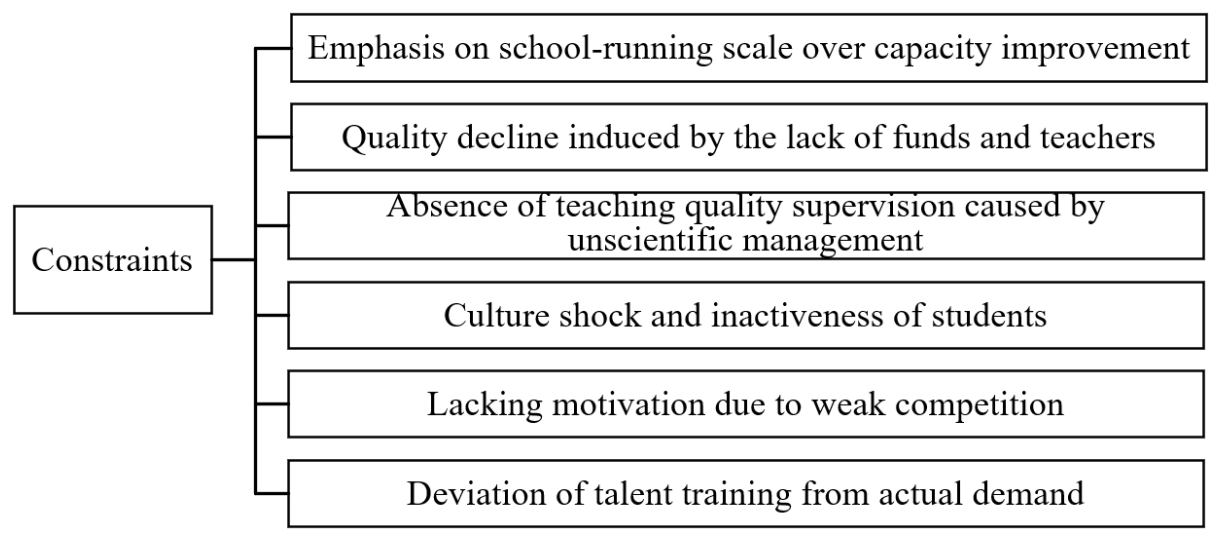

Fig. 4. Constraints on teaching quality appraisal in colleges

\section{$3 \quad$ KPI-based teaching quality comparison}

\subsection{Indices and methodology}

Figure 5 presents the key evaluation indices for teaching quality, teaching attitude, teaching content, teaching method, and teaching effect; the most important indices are teaching attitude and teaching content, followed by teaching effect and teaching method. Judging by the weight of each index, colleges attach the highest importance to the evaluation of teaching attitude and teaching content, and pay little attention to the evaluation teaching method.

Economic management is a course combining theory with practice. The students must not only learn theoretical knowledge, but also acquire practical ability of economy and management. Therefore, the students' evaluation should be emphasized in teachers' KPI appraisal. The student-centered appraisal focuses on teaching content and teaching effect. Meanwhile, the evaluation by peers, supervisors, and leaders stresses different aspects.

Our survey targets ordinary college students and vocational college students in Nanchang, the seat of eastern China's Jiangxi Province (Table 1). The objects are of different genders, types of colleges, teaching models, and departments.

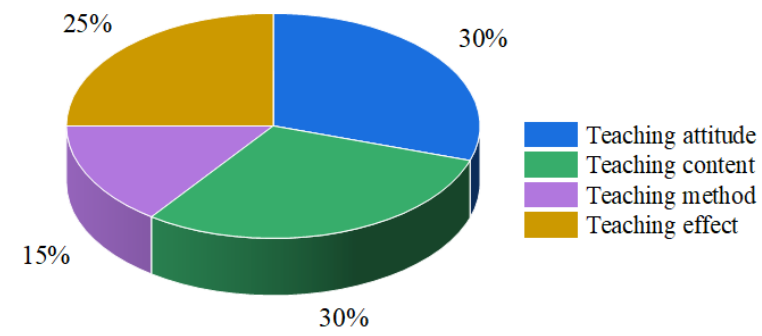

Fig. 5. Teaching quality evaluation indices 
Table 1. Objects of teaching quality evaluation

\begin{tabular}{|c|c|c|c|c|}
\hline \multicolumn{2}{|c|}{ Class } & & Number & Proportion \\
\hline \multirow{4}{*}{ Ordinary colleges } & \multirow{2}{*}{ Gender } & Male & 84 & $40.98 \%$ \\
\cline { 3 - 5 } & \multirow{2}{*}{ Teaching model } & Female & 121 & $59.02 \%$ \\
\cline { 3 - 5 } & & General education & 106 & $51.71 \%$ \\
\cline { 2 - 5 } & \multirow{2}{*}{ Department } & Professional education & 99 & $48.29 \%$ \\
\cline { 3 - 5 } & & Accounting & 134 & $65.37 \%$ \\
\cline { 3 - 5 } & \multirow{2}{*}{ Gocational colleges } & Business administration & 71 & $34.63 \%$ \\
\cline { 3 - 5 } & \multirow{2}{*}{ Gender } & Male & 97 & $45.33 \%$ \\
\cline { 3 - 5 } & & Female & 117 & $54.67 \%$ \\
\hline
\end{tabular}

As shown in Figure 6, teaching quality evaluation must be scientific, operable, incentive, guiding, as well as objective and fair. The evaluation should be carried out from the developmental perspective: teaching and learning must be unified, the performance of teachers and students in the entire teaching process must be scrutinized, and the appraisal must be implemented in strict accordance with the set rules.

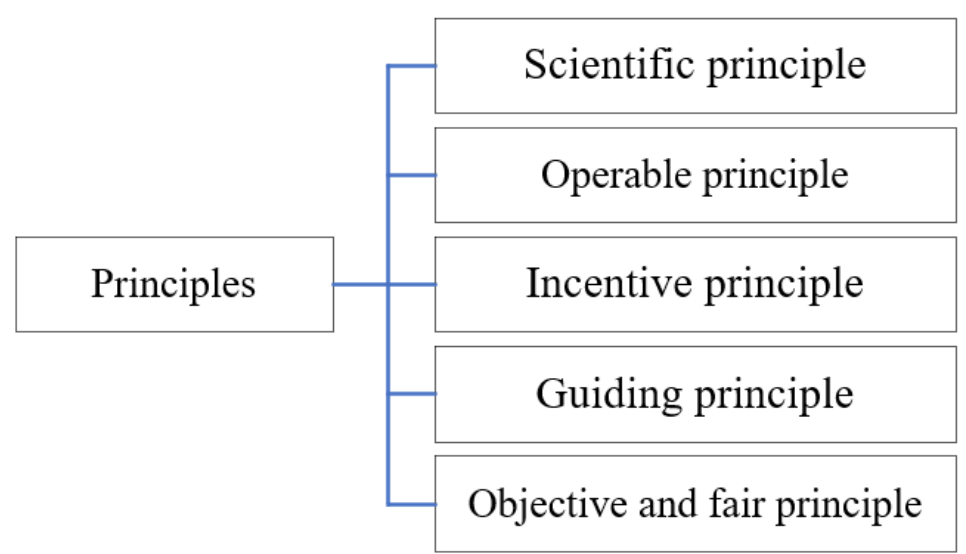

Fig. 6. Principles of teaching quality evaluation

The flow of college KPI appraisal is illustrated in Figure 7. Firstly, the Supervision Office of Teaching Affairs Department issues a notice of performance appraisal, and releases the relevant files. Next, each school summarizes the class hours and research results of their teachers; the teachers rate the performance of each other; the students rate the performance of the teachers, according to their teaching quality and ethics. All the ratings are given anonymously. After that, the Supervision Office collects the research results and ratings of the teachers, and sends the KPI appraisal results to the schools. 
Paper-Use of the Key Performance Index Evaluation Model for a Comparative Analysis of the...

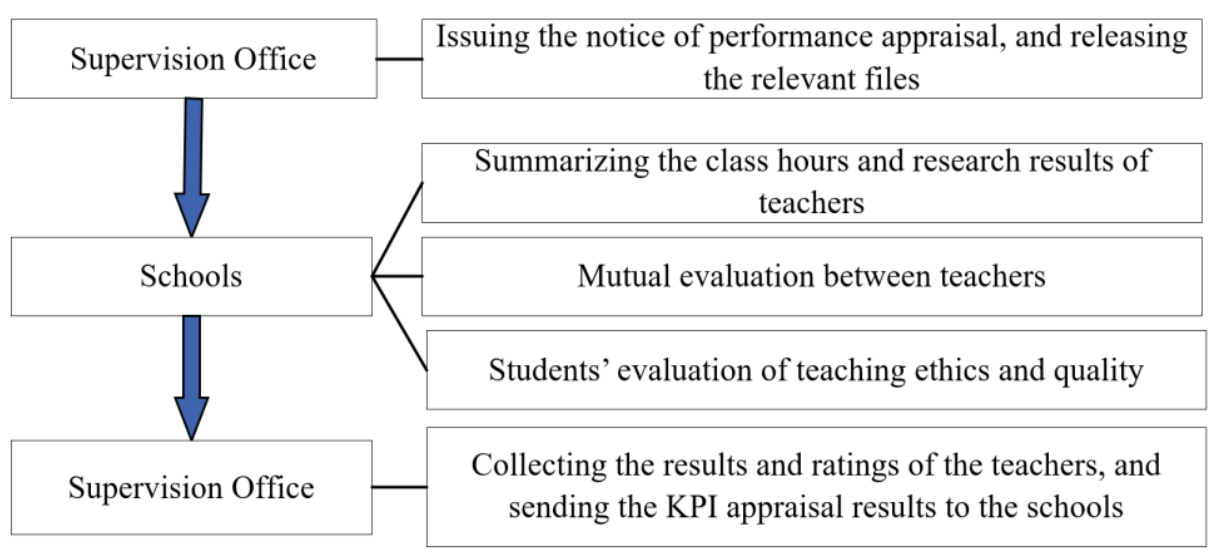

Fig. 7. Flow of college KPI appraisal

\subsection{Comparative analysis on teaching quality}

Economic management is featured by the deep integration between theory and practice. Students majoring in economic management need to acquire the skills of accounting and business administration at the same time. Figure 8 presents the professional differences between accounting and business administration. Obviously, the two disciplines have lots of overlapping learning areas. The difference is that accounting students need to master professional knowledge, extensive and integrated knowledge, and intellectual skills better than business administration students, while the latter need to do better in applied and collaborative learning.

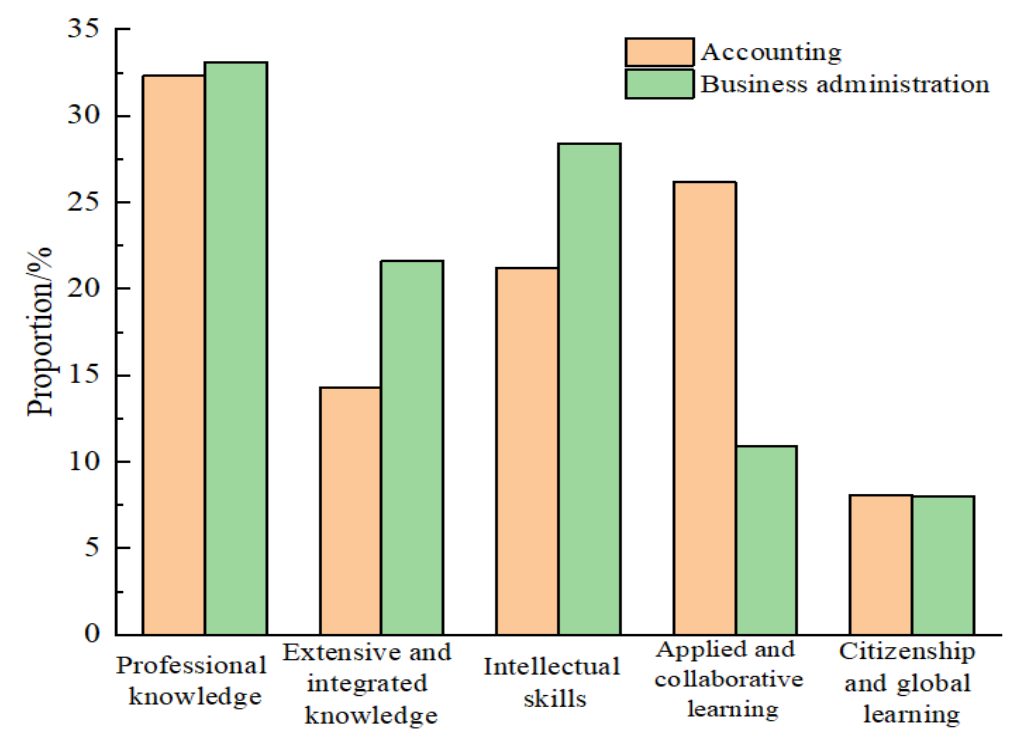

Fig. 8. Professional differences between accounting and business administration 
Figure 9 shows the teaching quality evaluation results of different types of colleges. In both ordinary colleges and vocational colleges, female students gave higher ratings on teaching quality than male students. Teaching quality is the highest rated index among ordinary college students, while teaching method is the highest rated index among vocational college students.

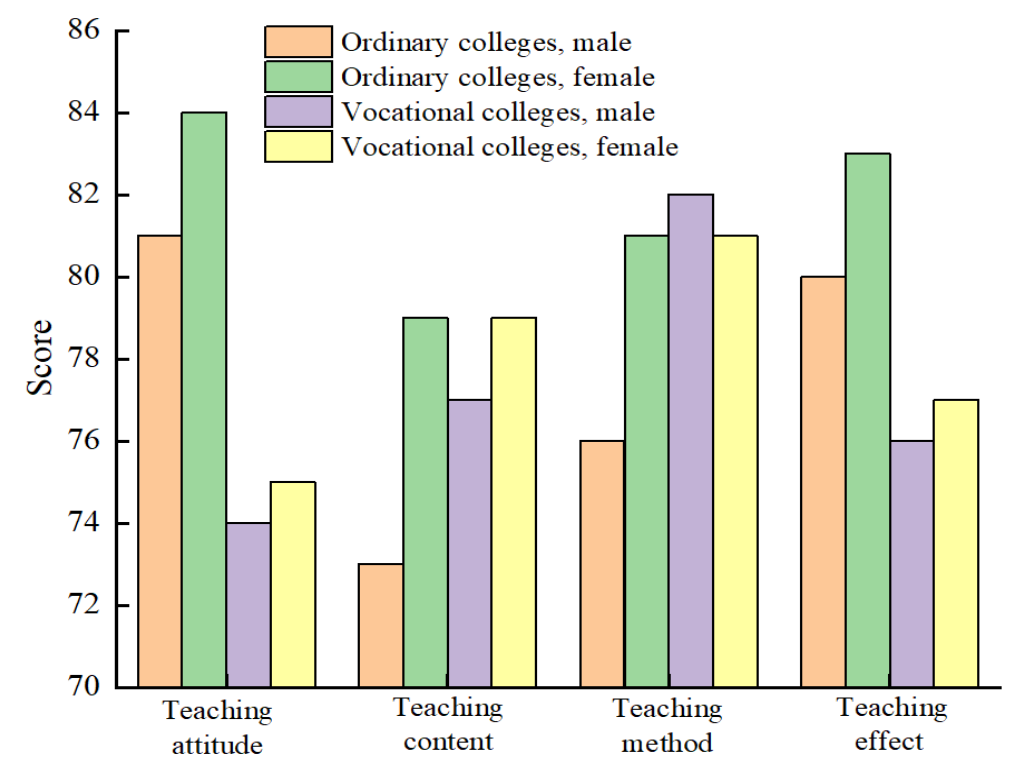

Fig. 9. Teaching quality evaluation results of different types of colleges

Figures 10 and 11 shows the teaching quality evaluation results of different teaching methods and disciplines, respectively. It can be observed that, the index scores of professional education mode were much higher than those of general education mode. Teaching effect is the highest rated index among students of accounting, and teaching attitude is the highest rated index among students of business administration. 


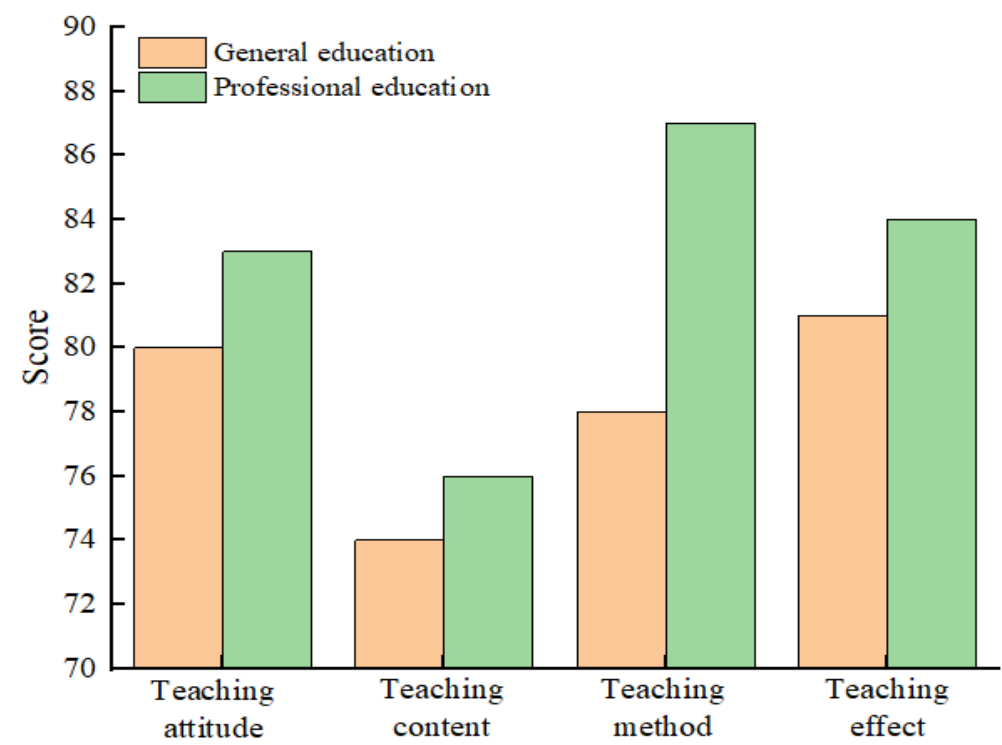

Fig. 10. Teaching quality evaluation results of different teaching methods

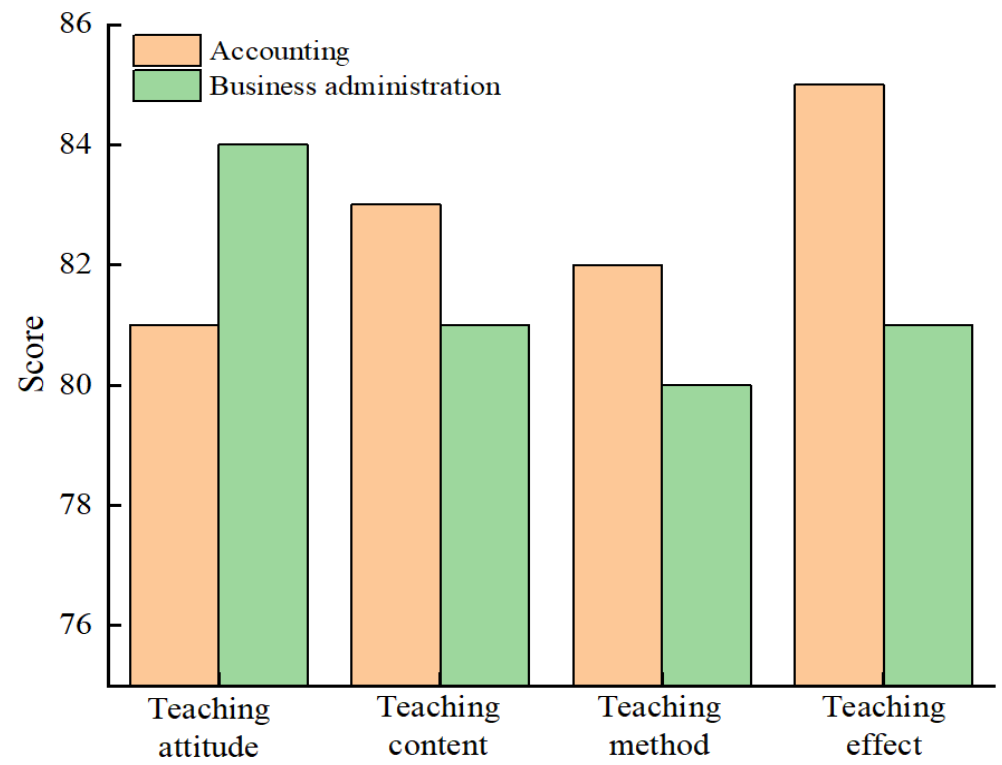

Fig. 11. Teaching quality evaluation results of different disciplines

\section{$4 \quad$ Optimization suggestions}

The core function of KPI appraisal is to achieve a win-win between college development and teacher development. This must be iterated in the implementation of KPI 
appraisal [27, 28]. Figure 12 summarizes our suggestions on how to optimize teachers' KPI appraisal.

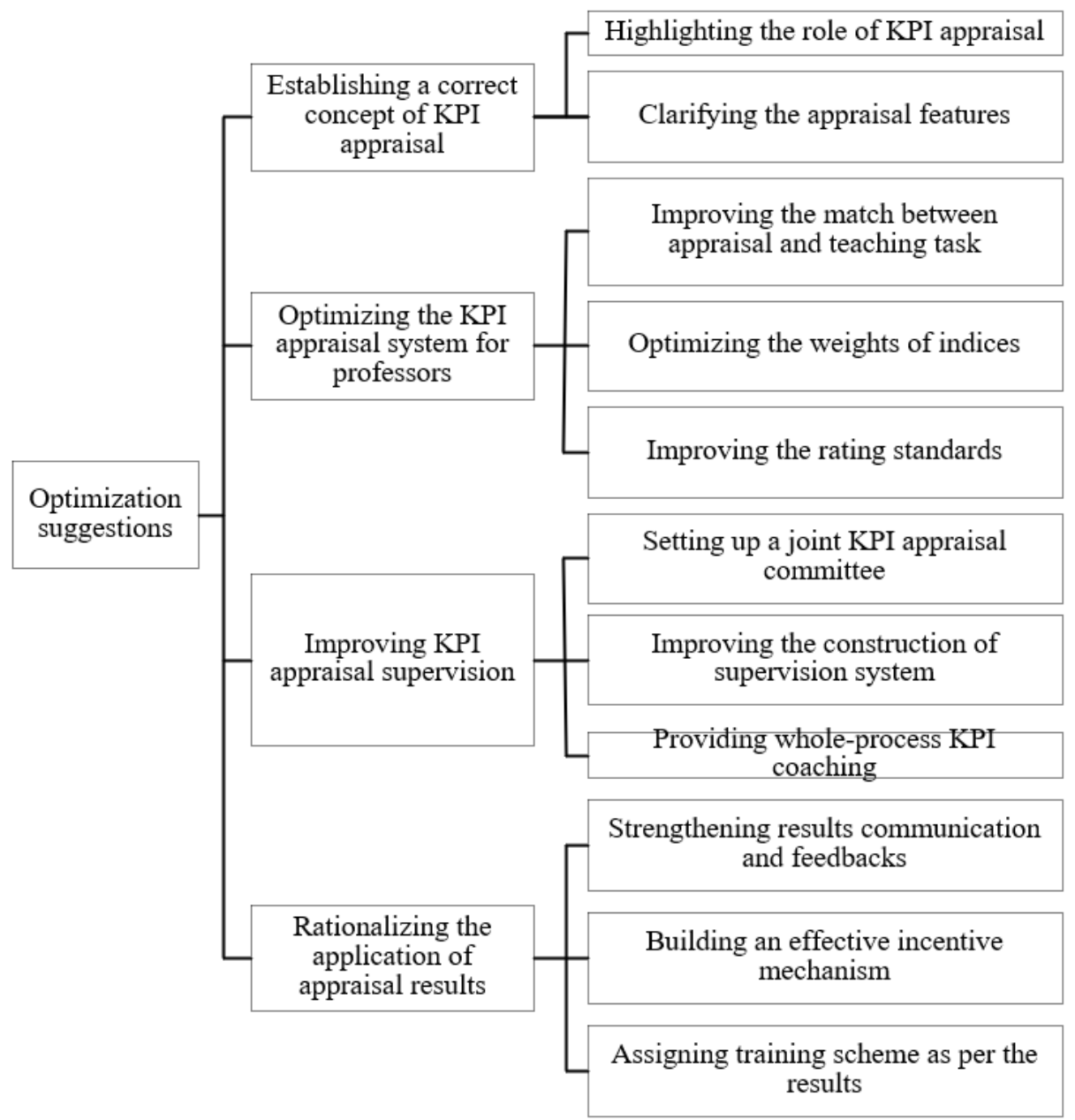

Fig. 12. Optimization suggestions

Firstly, it is necessary to establish a correct concept of KPI appraisal by highlighting the role of teachers' KPI appraisal, and clarifying the appraisal features.

Secondly, it is necessary to optimize the KPI appraisal system for professors by improving the match between appraisal and teaching task, optimizing the weights of indices, and improving the rating standards. Specifically, the appraisal should focus more on the teaching effect of frontline teachers, and the practical ability of students, rather than academic papers [29]. The relative importance of teaching and research must be clearly defined: teaching refers to the teachers' performance in professional quality, 
teaching skills, lecturing skills, and practical teaching; research can be quantified by books, inventions, research topics, and papers [30, 31].

Thirdly, it is necessary to improve KPI appraisal supervision by setting up a joint KPI appraisal committee, improving the construction of supervision system, and providing whole-process KPI coaching. Besides, a guarantee system should be built up with complete departments, reasonable staffing, perfect system, and sufficient funds [32]. In this way, KPI appraisal can find talents, cultivate excellent teachers, and align teacher development with college development [33].

Finally, it is necessary to rationalize the application of appraisal results by strengthening results communication and feedbacks, building an effective incentive mechanism, and assigning training scheme as per the results. The teachers' KPI appraisal should be combined with incentives. Only when a sound incentive mechanism is in place, could the teachers be mobilized to work actively, and fully utilize their strengths [34].

\section{Conclusions}

Based on KPI evaluation model, this paper compares the professional teaching quality of economic management of different types of colleges, different teaching models, and different disciplines, through KPI appraisal. The main conclusions are as follows:

1. Teaching quality can be evaluated by several important indices, namely, teaching attitude, teaching content, teaching method, and teaching effect; the most important indices are teaching attitude and teaching content, followed by teaching effect and teaching method.

2. Teaching quality is the highest rated index among ordinary college students, while teaching method is the highest rated index among vocational college students. The index scores of professional education mode were much higher than those of general education mode. Teaching effect is the highest rated index among students of accounting, and teaching attitude is the highest rated index among students of business administration.

3. The students' evaluation should be emphasized in teachers' KPI appraisal. The student-centered appraisal focuses on teaching content and teaching effect.

4. Teaching quality evaluation must be scientific, operable, incentive, guiding, as well as objective and fair.

\section{References}

[1] Latkin, A.P., Gorlov, A.V. (2020). Higher economic education as the basis of a new quality of management of the agro-industrial complex of the Far East. IOP Conference Series: Earth and Environmental Science, 547(1): 012028. https://doi.org/10.1088/1755-1315/547/1/ 012028

[2] Qi, Y.M., Wang, J.G. (2020). A Talent Cultivation Model for Improving the Innovation Ability of College Students in Scientific Research, International Journal of Emerging Technologies in Learning, 15(8): 151-164. https://doi.org/10.3991/ijet.v15i18.16745 
Paper-Use of the Key Performance Index Evaluation Model for a Comparative Analysis of the...

[3] Li, L., Zhang, K., Li, T. (2020). A Performance Analysis Model for the Training and Education of Information Security Talents, International Journal of Emerging Technologies in Learning, 15(5): 140-155. https://doi.org/10.3991/ijet.v15i05.13329

[4] Osei, E., Du, B., Hauck, L., Li, H., Tanter, A. (2017). Farm-level economic and water quality impacts of comprehensive nutrient management plan implementation in the ohio river basin. Jawra Journal of the American Water Resources Association, 53(3), 641-654. https://doi.org/10.1111/1752-1688.12518

[5] Ma, H.W., Lv, M., Lin, Y., Chen, X.L., Wang, D.P., Du, X.S., Li, J.B. (2020). Prawn (macrobrachium rosenbergii)-plant (hydrilla verticillata) co-culture system improves water quality, prawn production and economic benefit through stocking density and feeding regime manage. Aquaculture Research, 51(6): 2169-2178. https://doi.org/10.1111/are.14585

[6] Yilmaz, S., Burnak, N. (2013). An economic approach to the management of high-quality processes. Quality \& Reliability Engineering International, 29(5): 681-690. https://oi.org/ $\underline{10.1002 / \mathrm{qre} .1417}$

[7] Jones, L., Hohman, M., Mathiesen, S., Finnegan, D. (2014). Furloughs and faculty management of time: Maintaining quality in an economic crisis. Journal of Social Work Education, 50(2): 334-348. https://doi.org/10.1080/10437797.2014.856244

[8] Lavee, S., Avidan, B., Ben-Ari, G. (2014). Trends in breeding new olive varieties in Israel for quality and economic management. Agricultural Sciences, 5(8): 701-709. https://doi.org/10.4236/as.2014.58073

[9] Sinha, M., Sedevich Fons, L.A. (2011). Measuring economic effects of quality management systems. The TQM Journal, volume 23(4): 458-474. https://doi.org/10.1108/175427311 11139527

[10] Hankla, M.E., Kohn, C.S., Normand, M.P. (2017). Teaching college students to pour accurately using behavioral skills training: evaluation of the effects of peer modeling. Behavioral Interventions, 33(2): 136-149. https://doi.org/10.1002/bin.1509

[11] Prasad, S., Tata, J. (2003). The role of socio-cultural, political-legal, economic, and educational dimensions in quality management. International Journal of Operations \& Production Management, 23(5): 487-521. https://doi.org/10.1108/01443570310471839

[12] Aniskina, N., Terekhova, E. (2019). Innovative methods for quality management in educational organizations. International Journal of Quality \& Reliability Management, 36(2): 217231. https://doi.org/10.1108/ijqrm-12-2016-0235

[13] Egbetokun, S., Osabuohien, E.S., Akinbobola, T., Onanuga, O., Gershon, O., Okafor, V. (2019). Environmental pollution, economic growth and institutional quality: exploring the nexus in Nigeria. Working Papers of the African Governance and Development Institute, 31(1): 18-31. https://doi.org/10.1108/meq-02-2019-0050

[14] Manatos, M.J., Rosa, M.J., Sarrico, C.S. (2018). Quality management in universities: towards an integrated approach?. International Journal of Quality \& Reliability Management, 35(1): 126-144. https://doi.org/10.1108/ijarm-04-2016-0046

[15] Siddh, M.M., Soni, G., Jain, R., Sharma, M.K., Yadav, V. (2020). A framework for managing the agri-fresh food supply chain quality in Indian industry. Management of Environmental Quality, 32(2): 436-451. https://doi.org/10.1108/meq-05-2020-0085

[16] Sarrico, C.S., Rosa, M.J. (2016). Supply chain quality management in education. International Journal of Quality \& Reliability Management, 33(4): 499-517. https://doi.org/10.1108 /ijqrm-11-2014-0181

[17] Alexiou, C., Vogiazas, S., Solovev, N. (2020). Economic growth and quality of institutions in 27 postsocialist economies. Journal of Economic Studies, 47(4): 769-787. https://doi. org/10.1108/jes-02-2019-0069

[18] Zhu, F., Wang, L., Yu, M., Yang, X. (2020). Quality of conflict management in construction project context: conceptualization, scale development, and validation. Engineering Construction \& Architectural Management, 27(5): 1191-1121. https://doi.org/10.1108/ecam-09$\underline{2019-0497}$ 
Paper-Use of the Key Performance Index Evaluation Model for a Comparative Analysis of the...

[19] Udofia, E. E., Adejare, B.O., Olaore, G.O., Udofia, E.E. (2021). Direct and indirect impact of quality management on the integrated performance of medium-scale manufacturers. The TQM Journal. https://doi.org/10.1108/tqm-08-2020-0174

[20] Chowdhury, S.N., Eliwa, Y. (2021). The impact of audit quality on real earnings management in the UK context. International Journal of Accounting and Information Management, 29(3): 368-391. https://doi.org/10.1108/ijaim-10-2020-0156

[21] Apraiz, J.C., Richter, N. F., Antonio, J.M.D., Gudergan, S. (2020). The role of competitive strategy in the performance impact of exploitation and exploration quality management practices. European Business Review, 33(1): 1-27. https://doi.org/10.1108/ebr-09-2019$\underline{0182}$

[22] Wagner-Tsukamoto, S. (2018). For humanistic management and against economics. Business and Society Review, 123(3): 459-488. https://doi.org/10.1111/basr.12152

[23] Haas, T., Spielmann, N., Restin, T., Schmidt, A.R., Schmugge, M., Cushing, M.M. (2016). Economic aspects of intraoperative coagulation management targeting higher fibrinogen concentrations during major craniosynostosis surgery. Paediatric Anaesthesia, 26(1): 77-83. https://doi.org/10.1111/pan.12784

[24] Wang, J.N., Liu, H.C., Du, J., Hsu, Y.T. (2019). Economic benefits of technical analysis in portfolio management: Evidence from global stock markets. International Journal of Finance \& Economics, 24(2): 890-902. https://doi.org/10.1002/ijfe.1697

[25] Yang, S., Zhang, H. (2019). Practice and enlightenment of cooperation on PTRA for internship in A\&F economics \& management-a case of Heilongjiang Bayi Agricultural University. Creative Education, 10(04), 655. https://doi.org/10.4236/ce.2019.104048

[26] Pannell, D., Doole, G., Cheung, J. (2016). Antipodean agricultural and resource economics at 60: natural resource management. Australian Journal of Agricultural and Resource Economics, 60(4): 651-667. https://doi.org/10.1111/1467-8489.12172

[27] Roos, G. (2017). Knowledge management, intellectual capital, structural holes, economic complexity and national prosperity. Journal of Intellectual Capital, 18(4): 745-770. https://doi.org/10.1108/jic-07-2016-0072

[28] Kukartseva, O.I., Lobkov, K.Y., Tynchenko, S.V., Fedorova, N.V., Danilchenko, Y.V. (2020). Identification of the model elements for evaluating the management activities of an industrial enterprise based on kpi specification. Journal of Physics Conference Series, 1582(1): 012053. https://doi.org/10.1088/1742-6596/1582/1/012053

[29] Ramón Fuentes, Fuster, B., Lillo-Bauls, A. (2016). A three-stage DEA model to evaluate learning-teaching technical efficiency: Key performance indicators and contextual variables. Expert Systems with Applications, 48: 89-99. https://doi.org/10.1016/j.eswa.2015.11.022

[30] Blumberg, P., Becker, J.A. (2020). A call for a new model to evaluate teaching. National Teaching and Learning Forum, 29(2): 1-4. https://doi.org/10.1002/ntlf.30225

[31] Reymus, M., Liebermann, A., Diegritz, C., Keler, A. (2021) Development and evaluation of an interdisciplinary teaching model via 3D printing. Clinical and Experimental Dental Research, 7(1): 3-10. https://doi.org/10.1002/cre2.334

[32] Zhao, R. (2020). Construction of blended ESP teaching model and performance evaluation system in the context of "internet +". Journal of Physics Conference Series, 1634: 012022. https://doi.org/10.1088/1742-6596/1634/1/012022

[33] Zhao, B. (2021). Research on teaching ability evaluation model of university teachers based on computer big data theory. Journal of Physics: Conference Series, 1992(3): 032003. https://doi.org/10.1088/1742-6596/1992/3/032003

[34] Carty, A., Farrell, A.M. (2018). Co-teaching in a mainstream post-primary mathematics classroom: an evaluation of models of co-teaching from the perspective of the teachers: an evaluation of models of co-teaching. Support for Learning, 33(2): 101-121. https://doi.org/ $\underline{10.1111 / 1467-9604.12198}$ 
Paper-Use of the Key Performance Index Evaluation Model for a Comparative Analysis of the..

\section{$7 \quad$ Author}

Xiangpeng Chang, got the Master of Engineering degree from Wuhan University of Technology in 2012. He has been working in Management Department, Shijiazhuang University of Applied Technology since 2001. His main research areas are business management of tourism and hotel; and laws and regulations on tourism and hotel.

Article submitted 2021-09-23. Resubmitted 2021-10-27. Final acceptance 2021-10-30. Final version published as submitted by the author. 